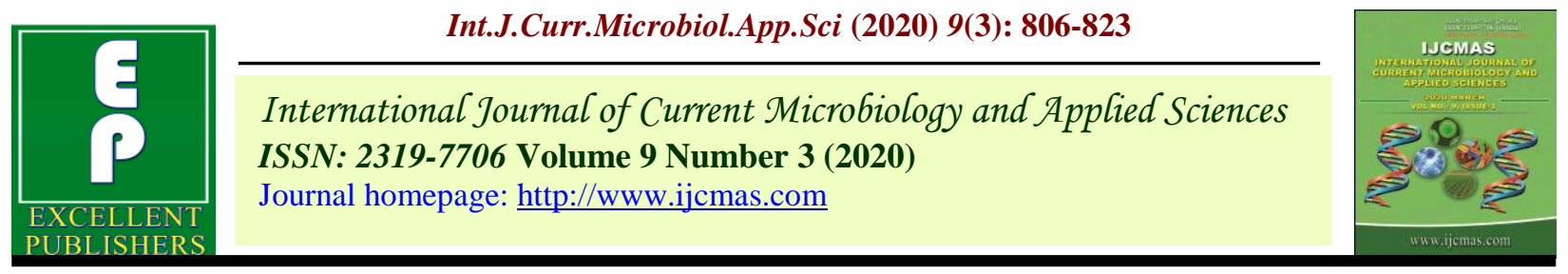

Original Research Article

https://doi.org/10.20546/ijcmas.2020.903.095

\title{
Effect of Feed Probiotic on the Growth and their Colonization Performance on the Intestine of Rohu (Labeo rohita)
}

\author{
Nityananda Das ${ }^{1 *}$, Sarita Das*, B. K. Khuntia and Brundaban Sahu \\ College of Fisheries (OUAT), Rangailunda, Berhampur-7, Ganjam, Odisha, India \\ *Corresponding author
}

\begin{tabular}{|l|}
\hline Ke y w o r d s \\
Probiotic, Feed, \\
Growth, Rohu \\
\hline Article Info \\
\hline Accepted: \\
05 February 2020 \\
Available Online: \\
10 March 2020 \\
\hline
\end{tabular}

\begin{abstract}
A B S T R A C T
The yearlings of Rohu (Labeo rohita) was fed with commercial pellated feed as $\mathrm{T}_{1}$ (Control), feed incorporated with Lactobacillus sporogenes @ 4\% as $\mathrm{T}_{2}$, Saccharomyces cerevisiae @ 4\% as $\mathrm{T}_{3}$ and both Lactobacillus sporogenes @2\% and Saccharomyces cerevisiae @2\% as $\mathrm{T}_{4}$.The experiment was designed for 120 days in the cement tanks. Feeding was done with probiotics and without probiotics at alternate 15 days. Sampling was done at an interval of 15 days. The samples were analysed to determine the weight gain $\%$, specific growth rate $\%$, FCR, FER and TPC of probiotic microbes. The average initial weight of fish in all treatment was about $44 \mathrm{~g}$. After feeding with probiotic incorporated feed, the weight increased to $150.78 \pm 0.68 \mathrm{gm}, 176.13 \pm 0.75 \mathrm{~g}$ and $183 \pm 0.91 \mathrm{~g}$ in $\mathrm{T}_{2}, \mathrm{~T}_{3}$ and $\mathrm{T}_{4}$ respectively as against $102.05 \pm 0.99 \mathrm{~g}$ in $\mathrm{T}_{1}$ (control). After first 15 days there were probiotic bacteria in all treatments except control. After next 15 days of feeding without probiotics, in all treatments (i.e. in 30 days) the TPC of probiotic microbe was found to be 0 in both $T_{1}$ and $T_{2}$ except $T_{3}$ and $T_{4}$. Likewise after 120 days the TPC of probiotic microbe in $\mathrm{T}_{1}$ and $\mathrm{T}_{2}$ was 0,but in $\mathrm{T}_{3}$ the Saccharomyces cerevisiae was $2.38 \pm 0.02 \times 10^{5} \mathrm{CFU} / \mathrm{g}$ and in $\mathrm{T}_{4}$ the Lactobacillus sporogenes was 0 and Saccharomyces cerevisiae was $2.70 \pm 0.008 \times 10^{5} \mathrm{CFU} / \mathrm{g}$. The growth in $\mathrm{T}_{4}$ was more due to more colony formation of Saccharomyces cerevisiae. Saccharomyces cerevisiae was found to colonized in the gut of fish after 15 days.
\end{abstract}

\section{Introduction}

Probiotics are live microbial feed supplements that beneficially affect the host by producing inhibitory compounds, competing for chemicals and adhesion sites, and modulating and stimulating immune function (Giri et al., 2012). Probiotics are also known to enhance the specific and non specific immune responses (Nayak, 2010). In the aquaculture industry, probiotics species of Bacillus
(Balcazar et al., 2004; Keysami et al., 2007), Lactobacillus (Abraham et al., 2007) and Saccharomyces (Rumsey et al., 2007) singly or mixed culture (Salinas et al., 2005; Ally et al., 2008; Mohapatra et al., 2012a, 2012b), are most commonly used. Bacteria are considered to be the most common cause of fish mortality in aquaculture, the motile Aeromonas, especially. Aeromonas hydrophila affects a wide variety of fresh water as well as marine fish species (Chu and 
Lu, 2005; Zhou et al., 2010). Probiotics are known to reduce the disease caused by $A$. hydrophila.

Selection of probiotics is very critical because in appropriate microorganisms can lead to undesirable effects in host. An ideal probiotics strain irrespective of its source should be able to colonize, establish and multiply in the host gut. Therefore, there is a general consensus that probiotics from autochthonous source have a great chance of competing with resident microbes and of becoming predominant within a short period of intake, which can assist in returning a disturbed micro biota to its normal beneficial composition and therefore enhanced the disease resistance of host.

Use of water and feed probiotics has become important part in aquaculture. The feed probiotics is defined as live microbial feed supplements that improve health of man, terrestrial livestock and aquatic animal. The gastrointestinal micro biota of fish and shellfish are peculiarly dependent on the external environment, due to the water flow passing through the digestive tract. Most bacterial cells are transient in the gut, with continuous intrusion of microbes coming from water and food. Some commercial products are referred to as probiotics, though they were designed to treat the rearing medium, not to supplement the diet. This extension of the probiotic concept is pertinent when the administered microbes survive in the gastrointestinal tract. Otherwise, more general terms are suggested, like bio control when the treatment is antagonistic to pathogens or bioremediation when water quality is improved. However, the first probiotics tested in fish were commercial preparations devised for land animals. Though some effects were observed with such preparations, the survival of these bacteria was uncertain in aquatic environment. Most attempts to propose probiotics have been undertaken by isolating and selecting strains from aquatic environment. These microbes were Vibrionaceae, pseudomonades, lactic acid bacteria, Bacillus spp. and yeasts. The use of probiotic in the form of single or mixed cultures of selected bacteria with feed to modify or manipulate the microbial communities in the gut. The feed probiotics micro flora in the gut play a major role in the digestion of food, helping in the breakdown of complex substances into simpler forms, which can be easily absorbed by the body. Many other beneficial effects may be expected from probiotics, e.g., competition with pathogens for nutrients or for adhesion sites, and stimulation of the immune system to improve the health, growth and survival of the host species. The most promising prospects are sketched out, but considerable efforts of research will be necessary to develop the applications to aquaculture. The research of probiotics for aquatic animals is increasing with the demand for environment friendly aquaculture. Among the aquatic species fish, rohu was selected for the research work as rohu is the most popular species among the carp.

Till date around 200 probiotics have been listed for use in various species of animals (Palod and Singh, 2004). The widely used probiotic cultures in aquaculture are: the yeast, Saccharomyces cerevisiae and the Lactobacillus species such as L. acidophilus and L. sporogenes. The information on the physiological parameters of growth when Saccharomyces cerevisiae and Lactobacillus. sporogenes cultures are used as probiotic growth promoters is scanty. Mixture of probiotics performs well (Schneitz et al., 1998). Though much work has been carried out on other aspects, more scientific and systematic approach on the basis for better digestibility, higher feed conversion and better growth and increase the survival rate 
needs to be elucidated. Therefore, the present study is undertaken with the following objectives to study the effects of Saccharomyces cerevisiae, Lactobacillus sporogenes and their combination.

From several researches it is proved that probiotics are of immense important in aquaculture in terms of increasing growth rate and disease resistant of fish etc. So to meet the increasing demand of animal protein to full fill the requirement of growing population it is advised to apply probiotics in aquaculture. Now a day's applications of probiotics are used to a greater extent keeping in view that to increase production. But probiotics which are available in the market are too costly. Large farmers are able to utilise probiotics but it is hardly possible for a marginal farmer to use it in fish culture. In other aspect continuous use of probiotics in fish culture increase the cost of cultivation which increases the expenditure. So keeping in view this above aspect this research is based on to reduce the cost in probiotic application which reduce the cost of cultivation and increase the profit of the farmer. In this research Sporolac powder available in the medicine shop are used as a source of Lactobacillus sporogenase and Backers yeast available in the bakery shop are used as a source of Saccharomyces cerevisiae are applied as feed by incorporate with commercial fish feed as probiotics. These bacteria and yeast are major contents in commercially available probiotics which are proven very effective in carp culture, especially in rohu culture. Our research is to find out the growth and the time period required for the colonization of that particular bacteria and yeast in the gut micro flora of rohu (Labeo rohita) which are used as probiotics after application with feed and in the time period without probiotic application.

Although Indian fresh water aquaculture has expanded rapidly over the last three decades, production remains limited to a few fresh water fish species. The three Indian major carps viz., catla (Catla Catla), rohu (Labeo rohita) and mrigala (Cirrhinus mrigala) contributes the bulk of the production while the three exotics carps, viz.- common carp (Cyprinus carpio), grass carp (Ctenopharyngodon idella) and silver carp (Hypophthalmichthys molitrix) formed the second important group. As a result, India is being referred as a carp country, with carps contributing to over $85 \%$ of the total aquaculture production in the country (Ayyappan et al., 2011). Among all major carps, rohu is the most preferable and most produced one with high flesh to bone ratio. So for our research the selection of species is rohu (Labeo rohita) only.

\section{Materials and Methods}

The present study was carried out on the effect of feed probiotic as yeast (Saccharomyces cerevisiae), bacteria (Lactobacillus sporogenes), and their combination (Saccharomyces cerevisiae and Lactobacillus sporogenes) in the applied commercial fish feed on the gut health and growth performance of rohu (Labeo rohita). In this case colonisation of fed microorganism on the gut was studied and simultaneously the growth of fish was also studied. The used different materials and methods for this purpose are described below.

\section{Experimental design}

Cement tanks (7mtx3mtx3mt) were washed properly and tank preparation was made as per CIFA technology. About 20 numbers of fishes were taken per tank. For each treatment 4 tanks were used. Experimental animals were segregated into following experimental groups. In Control $\left(\mathrm{T}_{0}\right)$ tanks application of Commercially available pellated floating feed @ 2\% of total body weight of stocked fish. In Treatment 1( $\left.\mathrm{T}_{1}\right)$ tanks application of 
commercially available pellated floating feed @ 2\% of total body weight of stocked fish with Lactobacillus sporogenes@4\% in the applied feed. In Treatment 2( $\left.\mathrm{T}_{2}\right)$ tanks application of Commercially available pellated floating feed @ 2\% of total body wt. of stocked fish with Saccharomyces cerevisiae @ 4\% in the applied feed.In Treatment $3\left(\mathrm{~T}_{3}\right)$ tanks application of Commercially available pellated floating feed @ 2\% of total body wt. of stocked fish with Lactobacillus sporogenes @ $2 \%$ in the applied feed and Saccharomyces cerevisiae @ $2 \%$ in the applied feed.

\section{Experimental site}

The experiment was conducted over a period of 120 days in the cement cisterns of College Of Fisheries Rangailunda, Ganjam, Odisha. Experiment was conducted in 16 numbers of rectangular cement tanks. One cement tank of size $7 \mathrm{mt} \times 3 \mathrm{mtx} 3 \mathrm{mt}$ size was made in to two tanks by putting a partition in the centre of the tank. The tanks are with inlet and outlet facilities and having water supply from bore well.

\section{Tank preparation}

At first the experimental tanks were siphoned properly to remove all the unwanted things. Then the tanks were poured with bleaching free bore-well water. As per CIFA technology tank were prepared and then the fish were stocked. The tanks were properly covered with net to avoid birds and reptiles to go inside the tanks.

\section{Probiotics}

The probiotics for the experimental study, viz., the Backers yeast(Angel),were used as a live source of Saccharomyces cerevisiae with 15 billion viable cells /g, the Sporolac powder were used as a live source of Lactobacillus sporogenase and having not less than 150 million spores of Lactic Acid Bacillus (Lactobacillus sporogenase)/gm.

\section{Experimental animals}

The yearlings of rohu (Labeo rohita) were procured from a private fish seed farm of chatrapur, Odisha weighing around 44.93 $\pm 2 \mathrm{gm}$ and the average length of about 14.06 $\pm 2 \mathrm{~cm}$ and used as experimental animal in the present study. Acclimatization of the fish was done in cement tank for 15 days only. The uniform size of fish was collected to stock in each tank. They were released @ 20 numbers per tank containing 200lt non - chlorinated bore well water. They were reared for 135days (15 days for acclimatization purpose and 120 days for experiment).The fishes were fed with commercial feed @ 2\% of their body weight twice daily. Samplings were done in every 15 days interval and analysis work was done for growth parameters and one fish was sacrificed for microbial colony observation, biochemical test and molecular test.

After 15 days of acclimatisation the sampling was done to know the initial growth parameters, presence of the probiotic microbe as Lactobacillus sporogenes and Saccharomyces cerevisiae and the presence of fish pathogen as Aeromonas hydrophila. Then next 15 days the fishes were fed with commercial feed with probiotics as Lactobacillus sporogenes @ 4\% of total applied feed in T2 tanks and Saccharomyces cerevisiae@4\% of total applied feed in T3 tanks and Lactobacillus sporogenes @ 2\% \& Saccharomyces cerevisiae @ 2\% of the total applied feed in T 4 tanks. In T 1 tanks the fishes were fed with normal feed. Next 15 days the fishes were fed with normal feed and sampling was done. In the next 15 days the fishes were fed with again the probiotic incorporated feed and sampling was done. Likewise the fishes were fed with normal feed 
for 15 days and probiotic in corporated feed for next 15 days and sampling was done up to 120 days.

\section{Commercial feed}

Commercially available pelleted floating fish feed were procured from the nearby market of company Growel Growfin having crude protein $32 \%$,crude fat $5 \%$ and crude fiber $5.5 \%$.

\section{Experimental feed}

Experimental feed were incorporated with probiotic in 3 ways as Lactobacillus sporogenase@4\% of the total applied feed, Saccharomyces cerevisiae @ 4\% of the total applied feed and Lactobacillus sporogenase @ 2\% of total applied feed and Saccharomyces cerevisiae @ 2\% of total applied feed by using commercially available binder Carboxymethyl cellulose (CMC).

\section{Media}

\section{Lactobacillus MRS Agar M641}

Lactobacillus MRS Agar is recommended for cultivation of all Lactobacillus species. Composition is given in the table 1 .

Directions: Suspend 67.15 grams in $1000 \mathrm{ml}$ distilled water. Heat to boiling to dissolve the medium completely. Sterilize by autoclaving at $15 \mathrm{lbs}$ pressure $\left(121^{\circ} \mathrm{C}\right)$ for 15 minutes. Mix well and pour into sterile Petri plates.

\section{YPG Agar M1368}

YPG Agar is recommended for the growth of Saccharomyces cerevisiae for molecular biology purpose. Composition is given in table 2

Directions: Suspend 50.0 grams in $1000 \mathrm{ml}$ distilled water containing $30 \mathrm{ml}$ glycerol.
Heat to boiling to dissolve the medium completely. Sterilize by autoclaving at $15 \mathrm{lbs}$ pressure $\left(121^{\circ} \mathrm{C}\right)$ for 15 minutes.

\section{Growth parameters}

Sampling was done at 15 days interval till 120 days to assess the weight gain by experimental animals. All the fishes in a tank were caught and bulk weighed without water by the help of an electronic balance. The initial weight and final weight was used to calculate the following growth parameters using the standard formulae (Samantaray and Mohanty, 1997).

Increment in weight $=$

Mean final weight of fish - Mean initial weight of fish

Percentage weight gain $=$

$\frac{\text { Final weight } \text { of fish }- \text { Initial weight of fish }}{\text { Initial weight of fish }} \times 100$

Daily weight gain $(\mathrm{g})=$

$\frac{\text { Final weight } \text { of fish }- \text { Initial weight of fish }}{\text { Total no . of experiment al days }}$

Feed conversion ratio $(\mathrm{FCR})=$

Dry feed fed in gm

Wet weight gain in gm

Feed efficiency ratio ratio $(\mathrm{FCR})=$

wet weight gain in gm

Dry feed fed in gm

\section{Estimation of microbial load}

The microbial load was estimated as per APHA, 1992. Sampling was done in each 15 
days interval and the fish of each tank were weighed. One fish from each tank was taken into laboratory with proper hygienic condition. It was cleaned with absolute alcohol, so that any contamination will not occur. Immediately fishes were dissected by using hygienic scissor. Gut content of the fish were bring out by using hygienic forceps. These fish were starved for $24 \mathrm{hr}$ and the intestine from all the fish were dissected out aseptically and about $1 \mathrm{gm}$ gut was taken out from each fish. The gut taken out was homogenized with $0.85 \% \mathrm{NaCl}$ solution (10:1). Fish intestine was homogenized by sterilized homogenizer with $10 \mathrm{ml}$ of sterilized saline water \& dilution of $10^{-3}, 10^{-4}$ $\& 10^{-5}$ was made by carrying serial dilution step wise through additional dilution tube. For Lactobacillus sporogenase, MRS Agar media \& for Saccharomyces cerevisiae YPG Agar media were used. Duplicate plates were made for $10^{-3}, 10^{-4} \& 10^{-5}$ dilution. $1 \mathrm{ml}$ sample was taken from each dilution \& poured in the petriplate. Then in a petriplate about $20 \mathrm{ml}$ of agar was poured \& allowed to solidify. Then the solidified plates were kept in incubator at $35{ }^{0} \mathrm{C}$ for $24-72 \mathrm{hrs}$. Likewise for YPG Agar plates were prepared with $1 \mathrm{ml}$ of each dilution and kept in room temperature at $30^{\circ} \mathrm{C}$ for 3-4 days for the formation of colony of Saccharomyces cerevisiae. The colony which was developed was counted and accordingly colony forming unit were calculated.

\section{Antimicrobial test}

Antimicrobial test was done by Agar well diffusion method by following the standard method of Magaldi et al., (2004). Agar well diffusion method is widely used to evaluate the antimicrobial activity of plants or microbial extracts. Similarly to the procedure used in disk-diffusion method, the MRS agar plate surface was inoculated by spreading a volume of the microbial inoculum of lactobacillus sporogenes over the entire agar surface. Then, a hole with a diameter of 6 to $8 \mathrm{~mm}$ is punched aseptically with a sterile cork borer or a tip, and a volume $(20-100 \mu \mathrm{L})$ of the Saccharomyces cerevisiae dilution with YPG agar media was introduced into the well. Likewise YPG agar plate surface was inoculated by spreading a volume of the microbial inoculum of Saccharomyces cerevisiae over the entire agar surface. Then, a hole with a diameter of 6 to $8 \mathrm{~mm}$ is punched aseptically with a sterile cork borer or a tip, and a volume $(20-100 \mu \mathrm{L})$ of the Lactobacillus sporogenes dilution with MRS agar media was introduced into the well.Then, agar plates are incubated under suitable conditions depending upon the test microorganism. The antimicrobial agent produced by the saccharomyces diffuses in the agar medium and inhibits the growth of the microbial strain of Lactobacillus sporogenes tested.

\section{Biochemical test}

After the conformation of bacteria and yeast by using particular media for further conformation biochemical tests were done. The biochemical test was done as per APHA, 1992. The tests are based on the principle of $\mathrm{pH}$ change and substrate utilization. Lactobacillus sporogenase and Saccharomyces cerevisiae on incubation exhibit metabolic changes which are indicated by a colour change in the media that can be either interpreted visually or after addition of reagent wherever required. The organism to be identified has to be first isolated and purified. Isolation is done by picking a loop of colony from a petriplate and grows them in slant of particular agar media. Pick up a single isolated colony and inoculate in $5 \mathrm{ml}$ nutrient broth and incubate at $35-37^{0} \mathrm{C}$ for 24 hours or further, until inoculum appears turbid. The isolated colony stored at $4{ }^{0} \mathrm{C}$ for further study. The following biochemical test were done like Staining Test, Catalase Test, Nitrate 
Reduction Test, Motility Test, VogesProskauer's Test, Methyl-Red Test and Carbohydrate Fermentation Test.

\section{Molecular test}

\section{Molecular test for Lactobacillus sporogenes}

DNA was isolated from the culture Lacto. Quality was evaluated on 1.2\% Agarose Gel, a single band of high-molecular weight DNA has been observed. Isolated DNA was amplified with $16 S$ rRNA Specific Primer (8Fand 1492R) using Veriti ${ }^{\circledR} 99$ well Thermal Cycler (Model No. 9902). A single discrete PCR amplicon band of $1500 \mathrm{bp}$ was observed (Figure 1). The PCR amplicon was enzymatically purified and further subjected to Sanger Sequencing. Bi-directional DNA sequencing reaction of PCR amplicon was carried out with $8 \mathrm{~F}$ and $1492 \mathrm{R}$ primers using BDT v3.1 Cycle sequencing kit on ABI 3730xl Genetic Analyzer. Consensus sequence of $1468 \mathrm{bp} 16 \mathrm{~S} r D N A$ was generated from forward and reverse sequence data using aligner software. The $16 S$ rDNA sequence was used to carry out BLAST alignment search tool of NCBI Genbank database. Based on maximum identity score first fifteen sequences were selected and aligned using multiple alignment software program ClustalW. Distance matrix was generated using RDP database and the Phylogenetic tree was constructed using MEGA5.

\section{Molecular test for Sacharomyces cerevisia}

DNA was isolated from the culture Sample. Quality was evaluated on 1.2\% Agarose Gel, a single band of high-molecular weight DNA has been observed. Isolated DNA was amplified with $18 S$ rRNA Specific Primer (1F and 4R) using Veriti ${ }^{\circledR} 99$ well Thermal Cycler (Model No. 9902). A single discrete PCR amplicon band of 900 bp was observed (Figure 1). The PCR amplicon was enzymatically purified and further subjected to Sanger Sequencing. Bi-directional DNA sequencing reaction of PCR amplicon was carried out with $1 \mathrm{~F}$ and $4 \mathrm{R}$ primers using BDT v3.1 Cycle sequencing kit on ABI 3730xl Genetic Analyzer. Consensus sequence of $896 \mathrm{bp}$ of $18 \mathrm{~S}$ gene in SSU region was generated from forward and reverse sequence data using aligner software. The $18 S$ gene in SSU region sequence was used to carry out BLAST alignment search tool of NCBI genbank database. Based on maximum identity score first ten sequences were selected and aligned using multiple alignment software program Clustal W. Distance matrix was generated using RDP database and the phylogenetic tree was constructed using MEGA 5.

\section{Statistical methodology}

The data were statistically analyze by statistical package SPSS version 16 in which data were subjected to one-way ANOVA and Completely Randomised Design (CRD) was used to determine the significant differences between the treatments.

\section{Results and Discussion}

The body weight of rohu yearlings at different days of observation in $\mathrm{T} 1, \mathrm{~T} 2, \mathrm{~T} 3$ and $\mathrm{T} 4$ are presented in Table-1. On the first day, the body weight in Treatment 1, 2, 3, 4 were $44.37 \pm 0.86,44.78 \pm 0.63,45.00 \pm 0.91$, $44.40 \pm 0.90$ respectively. It shows that all the yearlings are near about same in weight when they are ready for experimental work. In each 15 days interval the sampling was done up to 120 days. The final weight in T1, T2, T3 and T4 are also presented in Table- 2 as 102.05 $\pm 0.99,150.78 \pm 0.68,176.00 \pm 0.91$ and $183.00 \pm 0.91$ respectively. It shows that the growth of fish is more in the Treatment-4. The body weight gain in percentage and specific growth rate were represented in the 
Table -1. The weight gain percentage of the experimental sample was found to be very significant $(\mathrm{P}<0.05)$ among different treatment group at the end of the experimental period. Among the treatments the weight gain percentage in $\mathrm{T} 1$ was found to be significantly lower than other three treatments. Highest weight gain was recorded in T4 (311.25 \pm 7.2$)$ and the lowest was in T1 $(130.02 \pm 3.55)$. The FCR and FER values of the different experimental treatments were shown in the Table-1. All the treatments showed better FCR values are ranging from $1.705 \pm 0.01$ to $2.72 \pm 0.04$. In the treatment 4 the FCR value is the best as $1.705 \pm 0.01$. Similarly FER was observed and it was near about similar in all treatments with the value of $0.57 \pm 0.005$ in case of $\mathrm{T} 4$ and $0.57 \pm 0.01$ in $\mathrm{T} 3$ and $0.53 \pm 0.02$ in $\mathrm{T} 2$ and $0.37 \pm 0.005$ in $\mathrm{T} 1$. The enumeration of microbial load was done by TPC method. The Table-2 represents the microbial load of fish gut from the initial stage to the end of the experiment stage. Initially the load of Lactobacillus sporogenes and Saccharomyces cerevisiae was 0 in all the treatments. But after application of feed for 15 days the TPC in T1 was 0 where there is application of feed without probiotic, in T2 was $2.79 \pm 0.12 \times 10^{4}$ where application of feed with only Lactobacillus sporogenes, in T3 was 1.47 $\pm 0.02 \times 10^{5}$ where application of feed with Saccharomyces cerevisiae and in $\mathrm{T} 4$ where application of feed with both the probiotic microbe and Lactbacillus sporogenes was $1.23 \pm 0.03 \times 10^{4}$ and Saccharomyces cerevisiae was $1.74 \pm 0.01 \times 10^{5}$. Then another 15 days the normal feed was applied and like wise alternatively probiotic and normal feed was applied. After 120 days the TPC in T1 was 0 , in T2 was $2.82 \pm 0.06 \times 10^{4}$, in T3 was 2.38 $\pm 0.02 \times 10^{5}$ and in T4 was $2.70 \pm 0.008 \times 10^{5}$.

Different biochemical test were done for Lactobacillus sporogenase and Saccharomyces cerevisiae for confirmation after growing them in the particular media.
Biochemical test were done by application of particular reagent and the result was obtained either positive or negative according to the changes of colour. The result was given in the Table-3.This Table shows that Lactobacillus sporogenase is positive for staining, catalase, VP, methyl red, starch, fructose, lactose and negative for indole and nitrate reduction. It is a motile bacteria. But Saccharomyces cerevisiae is non motile and +ve for starch and fructose and -ve for nitrate reduction and lactose.

After biochemical test the species were confirmed that these are the species of Lactobacillus sporogenase and Saccharomyces cerevisiae. Still for better confirmation the gut sample was sent to the Xcelris Labs Ltd., Premchand Nagar Road, Bodakdev, Ahmedabad-380054, India for Identification of Bacterial Culture and yeast culture using $16 \mathrm{~S}$ rDNA based Molecular Technique and $18 S$ rDNA based Molecular Technique respectively. The result is mentioned below. The DNA band of Lactobacillus sporogenes in agarose is in Fig.1. The sequencing of Lactobacillus sporogenes was as follows: CTTCGGGTC CACCATCGGCGGCTGGCTCCGTAAGGT TACCTCACCGACTTC

\section{AGTCGGTGAGGTAACCTTACGGAGCC AGCCGCCGATGGTGGACCCGAAGTGG}

The Phylogenetic Tree of this species is in Fig. 2 and the DNA band of Saccharomyces cerevisiae in agarose is in Fig 3. The sequencing of Lactobacillus sporogenes was as follows:

TCCTGTGTGCCCGCACGCGCGGTAATT CCAGCTCCAATAGCGTATATTAAAGTT

AAGCCGATGGAAAGTTTGAGGCAATA ACACGTCAGTAATGCCCTCCGAACAC 


\section{Int.J.Curr.Microbiol.App.Sci (2020) 9(3): 806-823}

Table.1 Growth parameters of yearlings of Rohu

\begin{tabular}{|c|c|c|c|c|c|c|c|c|c|c|c|c|c|c|c|c|c|c|c|c|}
\hline Treatment & & & T1 & & & & & T2 & & & & & T3 & & & & & T4 & & \\
\hline Parameter & 1 & 2 & 3 & 4 & Average & 1 & 2 & 3 & 4 & Average & 1 & 2 & 3 & 4 & Average & 1 & 2 & 3 & 4 & Average \\
\hline $\begin{array}{l}\text { Initial } \\
\text { Weight (g) }\end{array}$ & 43.48 & 44.00 & 45.50 & 44.50 & $\begin{array}{l}44.37 \\
\pm 0.86\end{array}$ & 45.50 & 44.00 & 45.00 & 44.60 & $\begin{array}{l}44.78 \\
\pm 0.63\end{array}$ & 44.50 & 44.00 & 45.50 & 46.00 & $\begin{array}{l}45.00 \\
\pm 0.91\end{array}$ & 43.50 & 44.00 & 44.5 & 45.60 & $\begin{array}{l}44.4 \\
\pm 0.89\end{array}$ \\
\hline $\begin{array}{l}\text { Final } \\
\text { Weight (g) }\end{array}$ & 101.50 & 101.00 & 102.50 & 103.20 & $\begin{array}{l}102.05 \\
\pm 0.99\end{array}$ & 150.50 & 151.00 & 151.60 & 150.00 & $\begin{array}{l}150.78 \\
\pm 0.68\end{array}$ & 175.50 & 175.00 & 176.50 & 177.00 & $\begin{array}{l}176.00 \\
\pm 0.75\end{array}$ & 182.00 & 182.50 & 183.5 & 184.00 & $\begin{array}{l}183 \\
\pm 0.91\end{array}$ \\
\hline $\begin{array}{l}\text { Weight } \\
\text { gain }(\%)\end{array}$ & 58.02 & 57.00 & 57,00 & 58.70 & $\begin{array}{l}57.68 \\
\pm 0.83\end{array}$ & 105.00 & 107.00 & 106.60 & 105.40 & $\begin{array}{l}106.00 \\
\pm 0.95\end{array}$ & 131.00 & 131.00 & 131.00 & 131.00 & $\begin{array}{l}131.00 \\
\pm 0.50\end{array}$ & 138.50 & 138.50 & 139 & 137.40 & $\begin{array}{l}138.35 \\
\pm 0.67\end{array}$ \\
\hline $\begin{array}{l}\text { Weight } \\
\text { gain(\%) }\end{array}$ & 133.40 & 129.50 & 125.27 & 131.91 & $\begin{array}{l}130.02 \\
\pm 3.55\end{array}$ & 230.00 & 243.00 & 236.00 & 236.00 & $\begin{array}{l}236.25 \\
\pm 5.32\end{array}$ & 294.00 & 297.00 & 287.00 & 284.00 & $\begin{array}{l}290.5 \\
\pm 6.39\end{array}$ & 318.00 & 314.00 & 312 & 301.00 & $\begin{array}{l}311.25 \\
\pm 7.27\end{array}$ \\
\hline $\begin{array}{l}\text { Daily } \\
\text { weight } \\
\text { gain }(\%)\end{array}$ & 0.48 & 0.47 & 0.47 & 0.48 & $\begin{array}{l}0.48 \\
\pm 0.01\end{array}$ & 0.87 & 0.89 & 0.88 & 0.87 & $\begin{array}{l}0.88 \\
\pm 0.01\end{array}$ & 1.090 & 1.09 & 1.09 & 1.09 & $\begin{array}{l}1.09 \\
\pm 0.00\end{array}$ & 1.15 & 1.15 & 1.15 & 1.14 & $\begin{array}{l}1.1475 \\
\pm 0.00\end{array}$ \\
\hline $\begin{array}{l}\text { Specific } \\
\text { growth } \\
\text { rate }\end{array}$ & 0.71 & 0.69 & 0.67 & 0.71 & $\begin{array}{l}0.70 \\
\pm 0.02\end{array}$ & 0.99 & 1.03 & 1.01 & 1.01 & $\begin{array}{l}1.01 \\
\pm 0.02\end{array}$ & 1.150 & 1.16 & 1.12 & 1.12 & $\begin{array}{l}1.14 \\
\pm 0.02\end{array}$ & 1.19 & 1.19 & 1.18 & 1.16 & $\begin{array}{l}1.18 \\
\pm 0.01\end{array}$ \\
\hline $\begin{array}{l}\text { Total } \\
\text { feed fed } \\
\text { (g) }\end{array}$ & 155.25 & 156.00 & 158.10 & 158.5 & $\begin{array}{l}156.96 \\
\pm 1.58\end{array}$ & 199.65 & 200.70 & 199.20 & 199.80 & $\begin{array}{l}219.3 \\
\pm 1.26\end{array}$ & 219.30 & 218.85 & 220.35 & 222.90 & $\begin{array}{l}220.35 \\
\pm 1.81\end{array}$ & 234.90 & 235.50 & 237.3 & 237.90 & $\begin{array}{l}236.4 \\
\pm 1.42\end{array}$ \\
\hline $\begin{array}{l}\text { Food } \\
\text { conversio } \\
\text { n ratio }\end{array}$ & 2.67 & 2.73 & 2.77 & 2.70 & $\begin{array}{l}2.72 \\
\pm 0.04\end{array}$ & 1.90 & 1.86 & 1.86 & 1.89 & $\begin{array}{l}1.88 \\
\pm 0.02\end{array}$ & 1.670 & 1.67 & 1.68 & 1.70 & $\begin{array}{l}1.73 \\
\pm 0.01\end{array}$ & 1.69 & 1.70 & 1.7 & 1.73 & $\begin{array}{l}1.705 \\
\pm 0.01\end{array}$ \\
\hline $\begin{array}{l}\text { Food } \\
\text { efficiency } \\
\text { ratio }\end{array}$ & 0.37 & 0.36 & 0.36 & 0.37 & $\begin{array}{l}0.37 \\
\pm 0.00\end{array}$ & 0.52 & 0.53 & 0.53 & 0.52 & $\begin{array}{l}0.53 \\
\pm 0.01\end{array}$ & 0.59 & 0.59 & 0.59 & 0.58 & $\begin{array}{l}0.59 \\
\pm 0.01\end{array}$ & 0.58 & 0.58 & 0.58 & 0.57 & $\begin{array}{l}0.58 \\
\pm 0.00\end{array}$ \\
\hline
\end{tabular}


Table.2 Total Plate Count of probiotic microbe in muscle of Rohu in different days

\begin{tabular}{|c|c|c|c|c|c|c|c|c|c|c|c|c|c|c|c|c|c|c|c|}
\hline \multicolumn{2}{|c|}{\begin{tabular}{|l|} 
Duration \\
\end{tabular}} & \multicolumn{2}{|c|}{ Oday } & \multicolumn{2}{|c|}{15 days } & \multicolumn{2}{|r|}{30 days } & \multicolumn{2}{|c|}{ 45days } & \multicolumn{2}{|r|}{60 days } & \multicolumn{2}{|c|}{75 days } & \multicolumn{2}{|r|}{90 days } & \multicolumn{2}{|c|}{105 days } & \multicolumn{2}{|c|}{120 days } \\
\hline Treatment & Replication & $\mathrm{L}$ & S & $\mathrm{L}$ & S & $\mathrm{L}$ & S & $\mathrm{L}$ & S & L & S & $\mathrm{L}$ & S & $\mathrm{L}$ & S & $\mathrm{L}$ & S & $\mathrm{L}$ & $S$ \\
\hline \multirow{3}{*}{$\mathbf{T}_{1}$} & $\mathrm{R} 1$ & \multirow{3}{*}{0} & \multirow{3}{*}{0} & \multirow{3}{*}{0} & \multirow{3}{*}{0} & \multirow{3}{*}{0} & \multirow{3}{*}{0} & \multirow{3}{*}{0} & \multirow{3}{*}{0} & \multirow{3}{*}{0} & \multirow{3}{*}{0} & \multirow{3}{*}{0} & \multirow{3}{*}{0} & \multirow{3}{*}{0} & \multirow{3}{*}{0} & \multirow{3}{*}{0} & \multirow{3}{*}{0} & \multirow{3}{*}{0} & \multirow{3}{*}{0} \\
\hline & $\mathrm{R} 2$ & & & & & & & & & & & & & & & & & & \\
\hline & $\begin{array}{l}\text { R3 } \\
\text { R4 }\end{array}$ & & & & & & & & & & & & & & & & & & \\
\hline $\mathbf{A}$ & & 0 & 0 & 0 & 0 & 0 & 0 & 0 & 0 & 0 & 0 & 0 & 0 & 0 & 0 & 0 & 0 & 0 & 0 \\
\hline & $\mathrm{R} 1$ & 0 & 0 & $\begin{array}{l}2.95 \\
\times 10^{4}\end{array}$ & 0 & 0 & 0 & $\begin{array}{l}2.85 \\
\times 10^{4}\end{array}$ & 0 & 0 & 0 & $\begin{array}{l}2.80 \\
\times 10^{4}\end{array}$ & 0 & 0 & 0 & $\begin{array}{l}2.85 \\
\times 10^{4}\end{array}$ & 0 & 0 & 0 \\
\hline $\mathbf{T}_{2}$ & R2 & 0 & 0 & $2.75 \times 10^{4}$ & 0 & 0 & 0 & $2.80 \times 10^{4}$ & 0 & 0 & 0 & $2.85 \times 10^{4}$ & 0 & 0 & 0 & $2.90 \times 10^{4}$ & 0 & 0 & 0 \\
\hline & R3 & 0 & 0 & $2.65 \times 10^{4}$ & 0 & 0 & 0 & $2.75 \times 10^{4}$ & 0 & 0 & 0 & $2.65 \times 10^{4}$ & 0 & 0 & 0 & $2.80 \times 10^{4}$ & 0 & 0 & 0 \\
\hline & R4 & 0 & 0 & $2.80 \times 10^{4}$ & 0 & 0 & 0 & $2.65 \times 10^{4}$ & 0 & 0 & 0 & $2.90 \times 10^{4}$ & 0 & 0 & 0 & $2.75 \times 10^{4}$ & 0 & 0 & 0 \\
\hline $\mathbf{A}$ & & 0 & 0 & $\begin{array}{c}2.79 \\
\pm 0.12 \\
\times 10^{4}\end{array}$ & 0 & 0 & 0 & $\begin{array}{c}2.76 \\
\pm 0.08 \times 10^{4}\end{array}$ & 0 & 0 & 0 & $\begin{array}{c}2.80 \\
\pm 0.11 \times 10^{4}\end{array}$ & 0 & 0 & 0 & $\begin{array}{c}2.82 \\
\pm 0.06 \times 10^{4}\end{array}$ & 0 & 0 & 0 \\
\hline & R1 & 0 & 0 & 0 & $1.50 \times 10^{5}$ & 0 & $1.57 \times 10^{5}$ & 0 & $1.75 \times 10^{5}$ & 0 & $1.85 \times 10^{5}$ & 0 & $1.96 \times 10^{5}$ & 0 & $2.12 \times 10^{5}$ & 0 & $2.30 \times 10^{5}$ & 0 & $2.40 \times 10^{5}$ \\
\hline & $\mathrm{R} 2$ & 0 & 0 & 0 & $1.48 \times 10^{5}$ & 0 & $1.52 \times 10^{5}$ & 0 & $1.75 \times 10^{5}$ & 0 & $1.80 \times 10^{5}$ & 0 & $1.95 \times 10^{5}$ & 0 & $2.10 \times 10^{5}$ & 0 & $2.25 \times 10^{5}$ & 0 & $2.35 \times 10^{5}$ \\
\hline $\mathbf{T}_{\mathbf{3}}$ & R3 & 0 & 0 & 0 & $1.44 \times 10^{5}$ & 0 & $1.55 \times 10^{5}$ & 0 & $1.72 \times 10^{5}$ & 0 & $1.85 \times 10^{5}$ & 0 & $1.90 \times 10^{5}$ & 0 & $2.11 \times 10^{5}$ & 0 & $2.26 \times 10^{5}$ & 0 & $2.38 \times 10^{5}$ \\
\hline & $\mathrm{R} 4$ & 0 & 0 & 0 & $1.46 \times 10^{5}$ & 0 & $1.50 \times 10^{5}$ & 0 & $1.75 \times 10^{5}$ & 0 & $1.84 \times 10^{5}$ & 0 & $1.95 \times 10^{5}$ & 0 & $2.15 \times 10^{5}$ & 0 & $2.28 \times 10^{5}$ & 0 & $2.40 \times 10^{5}$ \\
\hline $\mathbf{A}$ & & 0 & 0 & 0 & $\begin{array}{c}1.47 \\
\pm 0.02 \times 10^{5}\end{array}$ & & $\begin{array}{c}1.53 \\
\pm 0.03 \times 10^{5}\end{array}$ & & $\begin{array}{c}1.74 \\
\pm 0.01 \times 10^{5}\end{array}$ & & $\begin{array}{c}1.83 \\
\pm 0.02 \times 10^{5}\end{array}$ & & $\begin{array}{c}1.94 \\
\pm 0.03 \times 10^{5}\end{array}$ & & $\begin{array}{c}2.12 \\
\pm 0.02 \times 10^{5}\end{array}$ & & $\begin{array}{c}2.27 \\
\pm 0.02 \times 10^{5}\end{array}$ & & $\begin{array}{c}2.38 \\
\pm 0.02 \times 10^{5}\end{array}$ \\
\hline & R1 & 0 & 0 & $1.20 \times 10^{4}$ & $1.72 \times 10^{5}$ & 0 & $1.80 \times 10^{5}$ & $1.27 \times 10^{4}$ & $1.98 \times 10^{5}$ & 0 & $2.08 \times 10^{5}$ & $1.25 \times 10^{4}$ & $2.30 \times 10^{5}$ & 0 & $2.38 \times 10^{5}$ & $1.21 \times 10^{4}$ & $2.60 \times 10^{5}$ & 0 & $2.70 \times 10^{5}$ \\
\hline & $\mathrm{R} 2$ & 0 & 0 & $1.27 \times 10^{4}$ & $1.75 \times 10^{5}$ & 0 & $1.85 \times 10^{5}$ & $1.21 \times 10^{4}$ & $2.0 \times 10^{5}$ & 0 & $2.09 \times 10^{5}$ & $1.27 \times 10^{4}$ & $2.28 \times 10^{5}$ & 0 & $2.40 \times 10^{5}$ & $1.23 \times 10^{4}$ & $2.62 \times 10^{5}$ & 0 & $2.71 \times 10^{5}$ \\
\hline $\mathbf{T}_{4}$ & R3 & 0 & 0 & $1.23 \times 10^{4}$ & $1.73 \times 10^{5}$ & 0 & $1.82 \times 10^{5}$ & $1.22 \times 10^{4}$ & $1.94 \times 10^{5}$ & 0 & $2.06 \times 10^{5}$ & $1.23 \times 10^{4}$ & $2.27 \times 10^{5}$ & 0 & $2.39 \times 10^{5}$ & $1.25 \times 10^{5}$ & $2.60 \times 10^{5}$ & 0 & $2.69 \times 10^{5}$ \\
\hline & $\mathrm{R} 4$ & 0 & 0 & $1.21 \times 10^{5}$ & 175000 & 0 & 184000 & $1.28 \times 10^{4}$ & 198000 & 0 & 207000 & $1.27 \times 10^{4}$ & $2.29 \times 10^{5}$ & 0 & $2.38 \times 10^{5}$ & $1.24 \times 10^{5}$ & $2.61 \times 10^{5}$ & 0 & $2.70 \times 10^{5}$ \\
\hline $\mathbf{A}$ & & 0 & 0 & $\begin{array}{c}1.23 \\
\pm 0.03 \\
\times 10^{4}\end{array}$ & $\begin{array}{c}1.73 \\
\pm 0.01 \times 10^{5}\end{array}$ & 0 & $\begin{array}{c}1.83 \\
\pm 0.02 \times 10^{5}\end{array}$ & $\begin{array}{c}1.24 \\
\pm 0.03 \times 10^{4}\end{array}$ & $\begin{array}{c}1.97 \\
\pm 0.02 \times 10^{5}\end{array}$ & 0 & $\begin{array}{c}2.07 \\
\pm 0.01 \times 10^{5}\end{array}$ & $\begin{array}{c}1.25 \\
\pm 0.01 \times 10^{4}\end{array}$ & $\begin{array}{c}2.28 \\
\pm 0.01 \times 10^{5}\end{array}$ & 0 & $\begin{array}{c}2.38 \\
\pm 0.09 \times 10^{5}\end{array}$ & $1.23 \pm 0.02$ & $\begin{array}{c}2.60 \\
\pm 0.01 \times 10^{5}\end{array}$ & 0 & $\begin{array}{c}2.70 \\
\pm 0.01 \times 10^{5}\end{array}$ \\
\hline
\end{tabular}

L- Lactobacillus sporogenes; S-Sachharomyces cerevisiae; AV-Average 
Table.3 Biochemical Test for microbe

\begin{tabular}{|c|c|c|c|}
\hline \multirow{2}{*}{$\begin{array}{l}\text { Sl. } \\
\text { No }\end{array}$} & \multirow[t]{2}{*}{ Name of Biochemical Test } & \multicolumn{2}{|c|}{ Result } \\
\hline & & Lactobacillus sporogenes & Saccharomyces cerevisiae \\
\hline 1. & Staining & Gram +ve & - \\
\hline 2. & Catalase & $+v e$ & - \\
\hline 3. & Nitrate reduction & -ve & -ve \\
\hline 4. & Motility & Motile & Non motile \\
\hline 5. & VP & $+v e$ & - \\
\hline 6. & Methyl red & $+v e$ & - \\
\hline 7. & Starch & +ve & +ve \\
\hline 8. & Fructose & +ve & +ve \\
\hline 9. & Indole & -ve & - \\
\hline 10. & Lactose & +ve & -ve \\
\hline
\end{tabular}

Note: +ve sign indicates the positive reaction, -ve sign indicates the negative reaction and - indicates the test is not necessary

Table.4 Results of ANOVA for CRD

\begin{tabular}{|c|c|c|c|c|}
\hline $\begin{array}{c}\text { Sources of } \\
\text { Variation }\end{array}$ & df & SS & MS & F \\
\hline Treatment & 3 & 1478.424 & 492.808 & 163.2274 \\
\hline Error & 8 & 24.1532 & 3.01915 & \\
\hline TOTAL & 11 & 1502.577 & & \\
\hline \multicolumn{5}{c}{ Critical difference (CD) $=9.3$} \\
\end{tabular}

Figure.1 1.2\% Agarose gel showing single $1500 \mathrm{bp}$ of $16 \mathrm{~S}$ rDNA amplicon. Lane 1: 100bp DNA ladder; Lane 2: 16S rDNA amplicon of Lactobacillus sporogenes

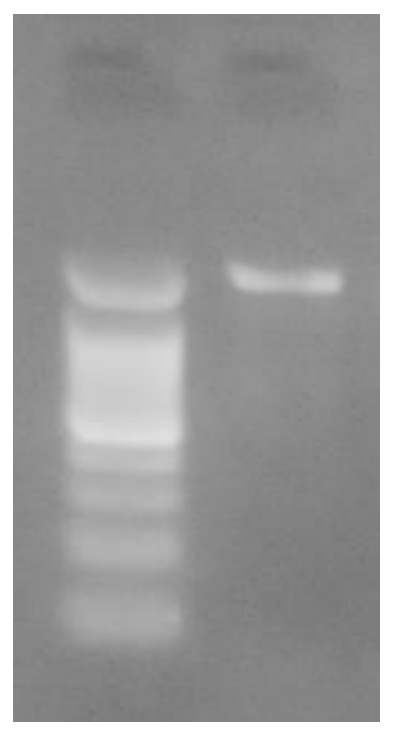


Fig.2 Phylogenetic tree of Lactobacillus sporogenes

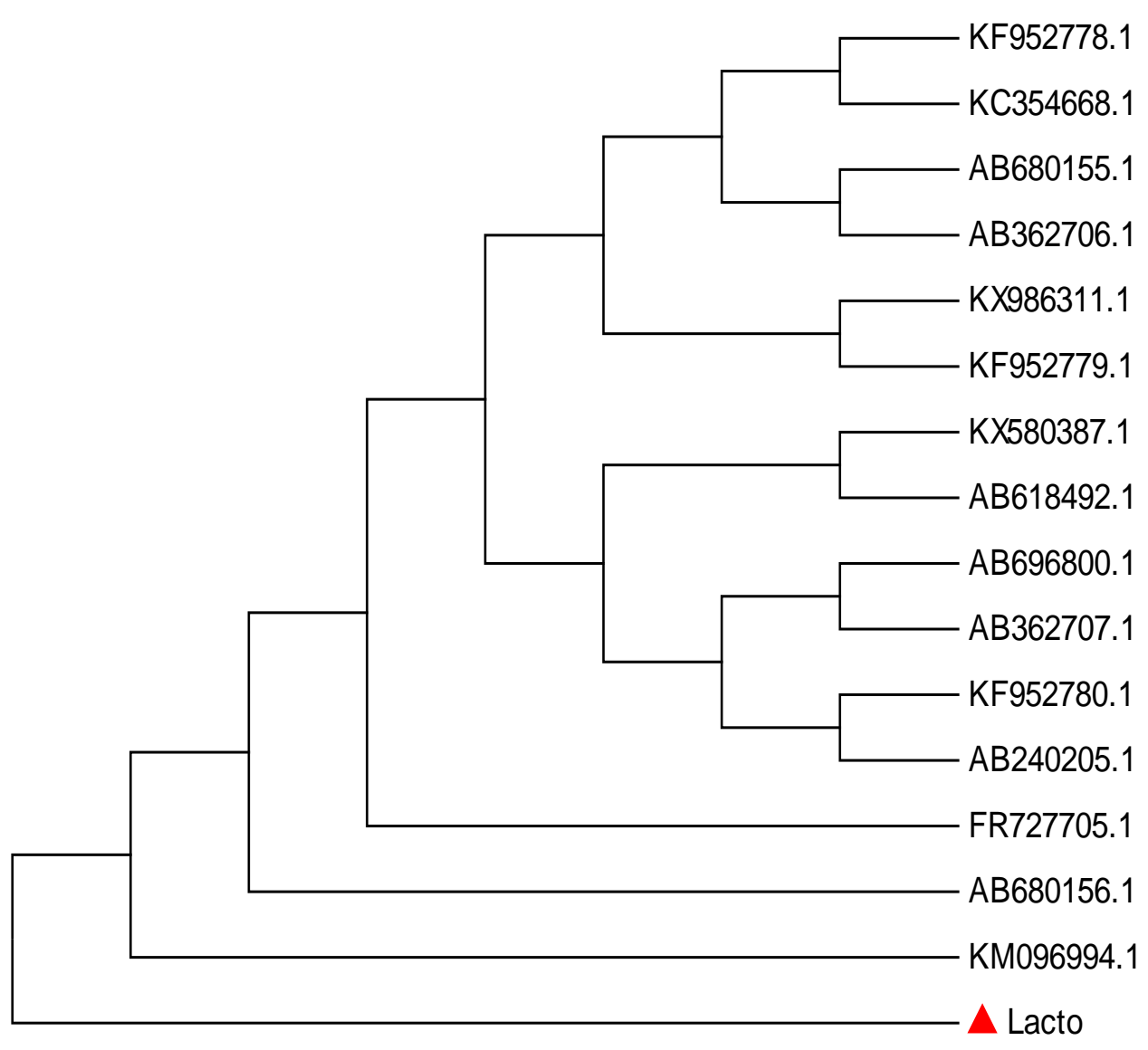

Figure.3 1.2\% Agarose gel showing 900bp amplicon (SSU region) of 18S rDNA. Lane 1: $100 \mathrm{bp}$ DNA Ladder and Lane 2: 900bp amplicon (SSU region) of $18 S$ rDNA of Saccharomyces cerevisiae

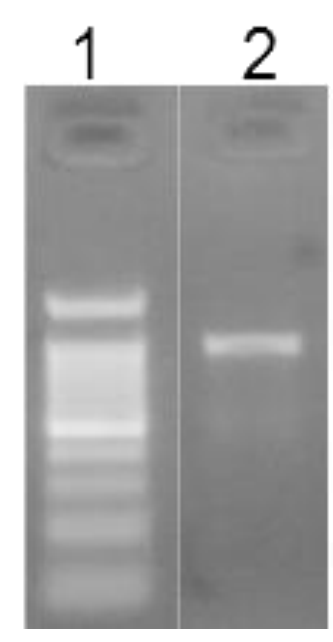


Fig.4 Phylogenetic tree of Saccharomyces cerevisiae

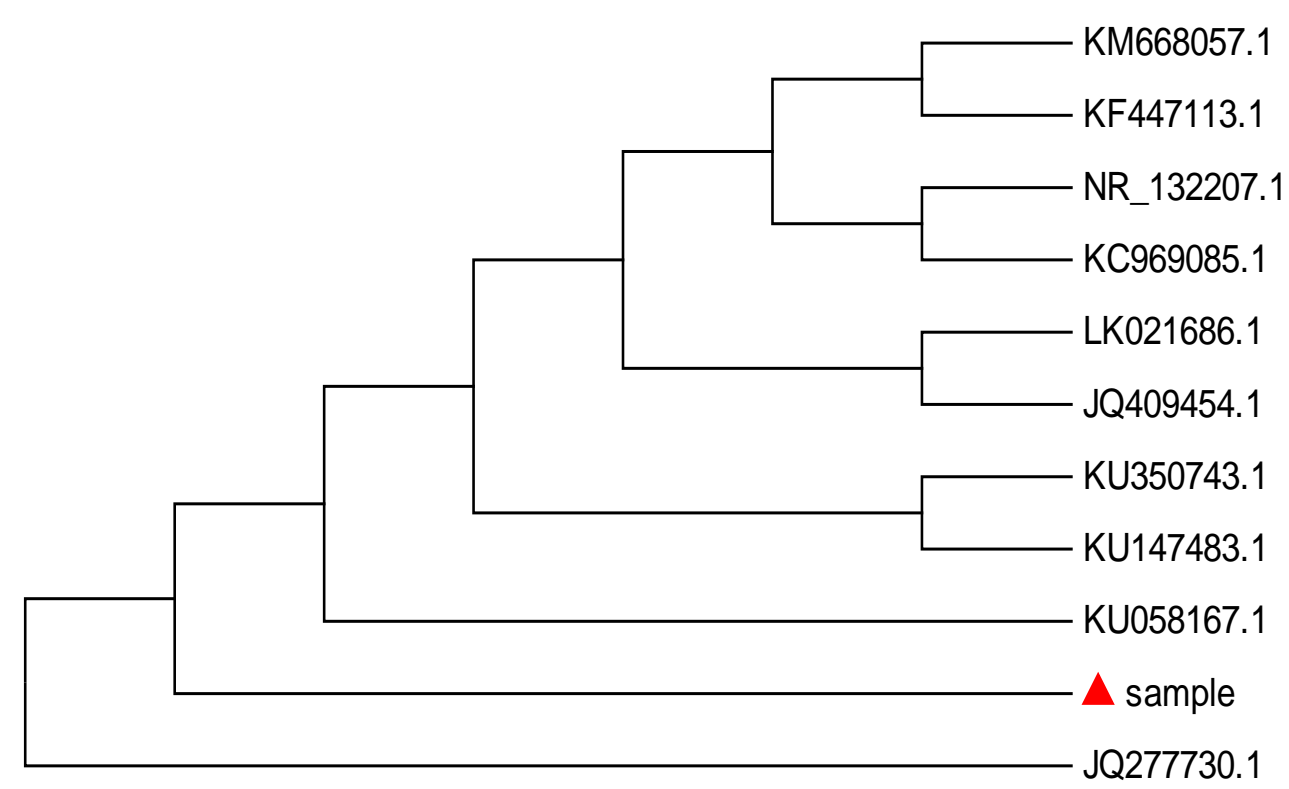

The phylogenetic tree of this species is in Fig 4. From this result it was confirmed that the species in the gut sample is Lactobacillus sporogenes and Sachharomyces cerevisiae which has been applied as probiotic in the fish feed.

In the present experiment the treatments are homogeneous with respect to the stocking density as well as the experimental area (cement tanks) and it is also laboratory based experiment. So completely randomized design is used to know the significant difference within the treatment and with treatment differs significantly. Here the calculated value found to be 6905.223 and tabulated value of $\mathrm{F}$ at $5 \%$ level of significant with $(3,12)$ d.f is 3.49 (Table-4). Calculated value $>$ tabulated value, at $5 \%$ level of significance. So it is concluded that there is a highly significant difference within the treatment means $(\mathrm{P}<0.05)$.Further to find out which of the treatment means differ significantly, CD (critical difference) value is compared with each treatment means. The treatment means of $\mathrm{T} 1, \mathrm{~T} 2, \mathrm{~T} 3$ and $\mathrm{T} 4$ are differed by more than $1.4(\mathrm{CD}$ value) indicate all the treatments differ significantly from one another. The mean weight of $\mathrm{T} 4$ recorded maximum weight gain and the minimum was recorded by $\mathrm{T} 1$ control. So it is concluded that the effect of T4 on growth performance was significantly superior to other treatments.

The initial and final weight of fish are represented in the Table 1.The final wt. of fish in T4 was the highest as $183 \pm 0.91 \mathrm{~g}$ and weight gain was $138.35 \pm 0.67 \%$ where the initial wt. of fish was $44.4 \pm 0.90 \mathrm{~g}$. The growth in $\mathrm{T} 1$ was less i.e.102.5 $\pm 0.99 \mathrm{~g}$, without the application of probiotic. This shows that growth of fish is increased due to the application of probiotic only. The Table 1 also shows that the specific growth rate is more in T4 i.e.114.75 \pm 0.5 and FCR is also less in the treatment 4 i.e. $1.705 \pm 0.01$. Again the feed efficiency ratio is more in $\mathrm{T} 4$ i.e. 0.57.This is due to mainly interaction of two probiotic bacteria as Lactobacillus sporogenes and Saccharomyces cerevisiae in T4. 
In the above experiment the feed was applied in @2\% of the total body wt. of fish and probiotic as Lactobacillus sporogenes was applied @ 4\% of total applied feed in T2 and Saccharomyces cerevisiae was applied @ 4\% of total applied feed in T3 and in T4.Lactobacillus sporogenes @ 2\% and Saccharomyces cerevisiae @ 2\% of the total applied feed. Here the experiment is designed in such a way that the normal feed is incorporated with probiotic bacteria and fed to the fishes for 15 days and next 15 days the fishes are fed with normal feed. Like wise it was continued for 120 days. The Table 1 and 2 shows that when fishes are fed with probiotic feed there is more growth than the application of normal feed. Again in Treatment 4, the growth is more as there is an interaction between the two species. So the growth in $\mathrm{T} 4$ is more than $\mathrm{T} 3$ than $\mathrm{T} 2$ than T1.Because there is interaction between two species in T4, more colonization of Saccharomyces cerevisiae in T3, non colonisation of Lactobacillus sporogenes in T2 and application of normal feed in T1(control). Similar application was done by Gupta and Dhawan, 2012.An investigation was carried out by them to determine the effect of adding probiotic 'Improval', containing bacteria Lactobacillus sporogenes and the yeast Saccharomyces cerevisiae as growth promoters, in the diet of freshwater prawn (Macrobrachium rosenbergii) during the post larval stage of growth. Post larvae (nos. $=450 ; 0.38 \pm 0.02 \mathrm{~g}$ mean weight) were divided into five experimental groups each with three replicates.

The experiment was conducted for 60 days. Control diet (CD) had no Improval, diet 1 (D1), 2 (D2), 3 (D3) and 4 (D4) contained 2, 4, 6 and $8 \%$ Improval, respectively. Significantly $(\mathrm{P}<0.05)$ higher growth for final body weight $(16.14 \pm 3.57 \mathrm{~g})$, net body weight gain $(15.76 \pm 3.24 \mathrm{~g})$ and specific growth rate $(7.50 \pm 0.38 \%$ body weight day-1) was recorded in groups of prawn fed diet containing 4\% Improval (D2). In addition, the feed conversion ratio and protein efficiency ratio in treatments receiving 'Improval' as growth promoters were significantly $(\mathrm{P}<0.05)$ better than those fed the control diet. The protein content of carcass showed the highest value for prawn fed diet D2 $(65.3 \pm 2.21 \%)$ and the lowest was observed in D4 $(58.9 \pm 2.5 \%)$. No significant differences were observed in lipid content among groups of prawn fed diet D1, D4 and CD, while the best and lowest values of lipid carcass were recorded for those fed on D2 $(7.14 \pm 0.98 \%)$ and D3 $(7.63 \pm 0.77 \%)$. The result suggests that the addition of probiotic 'Improval' as growth promoter in the diet @ 4\% improved the growth performance of Macrobrachium rosenbergii post larvae. Similar type of experiment was designed by Mohapatra et al., in 2012. They studied the different microbial probiotic in the feed of rohu fingerlings on the growth, nutrient digestibility, digestive enzyme activities and intestinal microflora. Lara-Flores et al., 2003 also used the bacteria Streptococcus faecium and Lactobacillus acidophilus and the yeast Saccharomyces cerevisiae as growth promoter in nile tilapia (Oreochromis niloticus).

Sreenivasan et al., studied the effect of Lactobacillus sporogenes on survival, growth, biochemical constituents and energy utilization of fresh water prawn Macrobrachium rosenbergii post larvae. They used the probiotic in different level and he observed that @ 4\% level the growth is more than $1 \%, 2 \%$ and $3 \%$ and observed that weight gain in gm was 1.22 and specific growth rate was $0.989 \%$ for the culture period 90 days in cement tank. Likewise Aderolu et al., (2011) used baker's yeast Saccharomyces cerevisiae in the feed of juvenile of catfish (Clarius gariepinus). He applied probiotic $@ 0 \%, 2 \%, 4 \%, 6 \%$ and $8 \%$ and observed the growth is more in $4 \%$. The wt. gain in gm was 174.80, specific growth rate was $3.75 \%$ and FCR was 0.56. Marzouk et al., (2008) studied 
the influence of some probiotic on the growth performance and intestinal microflora of Oreochromis niloticus. He used Bacillus subtilis and Saccharomyces cerevisiae and observed that the weight gain was $12.3 \%$ when feed was applied @ $3 \%$ of total biomass and probiotic applied $1.5 \mathrm{~g} / \mathrm{kg}$ of feed. FCR was 4.73 and specific growth rate $\mathrm{g} /$ day was. 0096.

The microbial load for probiotic bacteria was represented in the Table-3.Initially the probiotic microbial load of stocked fish was zero. When the applied feed was incorporated with probiotic bacteria as Lactobacillus sporogenes in T2 and Saccharomyces cerevisiae in $\mathrm{T} 3$ and both in $\mathrm{T} 4$, then there was probiotic microbial load. After 15 days the the probiotic bacteria was zero in $\mathrm{T} 1$ (Control). But in T2 it was $2.79 \pm 0.12 \times 10^{4}$, i.e is the load of only Lactobacillus sporogenes as the applied feed is incorporated with only the sporolac powder. But in T3 it was 1.47 $\pm 0.02 \times 10^{5}$ as the application of feed is with Saccharomyces cerevisiae (baker's yeast powder) and in T4 where application of feed with both the probiotic microbe and Lactobacillus sporogenes was $1.23 \pm 0.03 \times 10^{4}$ and Saccharomyces cerevisiae was $1.74 \pm 0.01$ $\mathrm{x} 10^{5}$. The experiment was designed in such a way that application of probiotic feed is for 15 days and next 15 days for normal feed up to 120 days. So when in the next 15 days i.e. in 30 days there was application of normal feed and the microbial load was o in T2. But in T3 there was a microbial load of Saccharomyces cerevisiae i.e.1.53 \pm 0.03 $\mathrm{x} 10^{5}$. So it shows that the yeast colonizes in the gut of fish after 15 days of application of probiotic incorporated feed. Like wise in T4 there was only the microbial load of Saccharomyces cerevisiae i.e. $1.83 \pm 0.02 \times 10^{5}$ as Lactobacillus sporogenes do not colonize in the gut of fish. Again when for next 15 days there was application of probiotic feed, in all treatments except T1 there was microbial load and when next 15 days there was only application of normal feed there was microbial load of Saccharomyces cerevisiae in T3 and T4 as it has already been colonized in the gut of fish. So after 120 days the probiotic microbial load in T1 (control) was 0 , in T2 was also 0 in $\mathrm{T} 3$ was $2.38 \pm 0.02 \times 10^{5}$ and in T4 was $2.70 \pm 0.008 \times 10^{5}$ as there was application of normal feed for last 15 days, so Lactobacillus sporogenes is not colonized in the gut.

The enumeration of microbial load was done by TPC method. The Table- 2 represents the microbial load of fish gut from the initial stage to the end of the experiment stage. Initially the load of Lactobacillus sporogenes and Saccharomyces cerevisiae was 0 in all the treatments. But after application of feed for 15 days the TPC in T1 was 0 where there is application of feed without probiotic, in $\mathrm{T} 2$ was $2.79 \pm 0.12 \times 10^{4}$ where application of feed with only Lactobacillus sporogenes, in T3 was $1.47 \pm 0.02 \times 10^{5}$ where application of feed with Saccharomyces cerevisiae and in T4 where application of feed with both the probiotic microbe and Lactbacillus sporogenes was $1.23 \pm 0.03 \times 10^{4}$ and Saccharomyces cerevisiae was $1.74 \pm 0.01$ $\mathrm{x} 10^{5}$. Then another 15 days the normal feed was applied and likewise alternatively probiotic and normal feed was applied. After 120 days the TPC in T1 was 0 , in T2 was $2.82 \pm 0.06 \times 10^{4}$, in $\mathrm{T} 3$ was $2.38 \pm 0.02 \times 10^{5}$ and in T4 was $2.70 \pm 0.008 \times 10^{5}$.

The Fig. 1 shows that the Saccharomyces cerevisiae has antimicrobial activity against the Lactobacillus sporogenes. So there was no growth of Lactobacillus sporogenes in the plate. Buyuksirit and Kuleasan (2014) reported that the killing effect of Saccharomyces cerevisiae on other species of yeast and bacteria as it produces some toxin. Roostita et al., (2011) and Li et al., (2012) reported that many yeast strains secrete toxins for inhibiting the growth of other yeast strains and these yeast have antimicrobial activity 
inhibiting the growth of molds and bacteria.

After confirmation of species in the selective media, biochemical test was also done for better confirmation. Table- 3 shows that Lactobacillus sporogenes is +ve for Catalase, lactose, fructose, starch, VP, Methyl red test and -ve for nitrate reduction and indole. Like wise Saccharomyces cerevisiae is +ve for fructose, starch and -ve for nitrate reduction and lactose.

Venkat et al., (2004) studied the effect of feeding lactobacillus -based probiotics on the gut microflora, growth and survival of post larvae of Macrobrachium rosenbergii (de Man). They have done the biochemical test for the Lactobacillus acidophilus and Lactobacillus sporogenes. Gobinath and Gobinath and Ramanibai (2012) studied the effect of probiotic bacteria culture on pathogenic bacteria from fresh water fish Oreochromis mossambicus. According to him Lactobacillus sps. produced indole, methyl red, VP, nitrate reduction, catalase and oxidase -ve, but +ve for citrate utilization, urease, fructose, glucose and lactose. Dhanasekaran et al., (2010) studied the effect of Lactobacillus isolates against bacterial pathogens in fresh water fish. They observed different biochemical characteristics of Lactobacillus isolates. Vaseeharan et al., (2004) studied the effect of probiotics, antibiotic sensitivity, pathogenicity and plasmid profiles of Listonella anguillarum like bacteria isolated from Penaeus monodon culture system. Ghosh (2011) studied 13 species of yeast from fruit of Syzygium cumini (Linn) skeel by biochemical characteristics.

After biochemical test the species were confirmed that these are the species of Lactobacillus sporogenase and Saccharomyces cerevisiae. Still for better confirmation the gut sample was sent to the Xcelris Labs Ltd., Premchand Nagar Road,
Bodakdev, Ahmedabad-380054, India for Identification of Bacterial Culture and yeast culture using $16 \mathrm{~S}$ rDNA based Molecular Technique and $18 S$ rDNA based Molecular Technique respectively. The blast result shows that one of the Lactobacillus sporogenes sample is $99 \%$ similar with Bacillus Coagulans and the sample of Saccharomyces cerevisiae is also $99 \%$ similar with the species of Saccharomyces cerevisiae.

Thankappan et al., (2015) characterized the Bacillus spp. from the gastrointestinal tract of Labeo rohita - towards to Identify Novel Probiotics Against Fish Pathogens. The 16S rRNA gene of the isolates were amplified using Universal 27 F Forward (5'CCAGAATTCAGAGTTTGATCMTGGCTC A-3'), and 1492R reverse (5'-ACCAAGCT TTACGGYTACCTTGTTAGGACTT-3') primers in a Thermal cycler (Eppendorf). Vijayaram et al., (2016) isolated and characterized the probiotic bacteria from diverse fish fauna of the trodden Vaigai river at Theni district by using the 16s rRNA sequencing method. Venkatalakshmi and Ebanasar (2015) isolated gastrointestinal microbiota in Oreochromis mossambicus (Peters) and Oreochromis niloticus (Linnaeus) by $16 \mathrm{~S}$ rDNA sequencing. The total of seven strains isolated from gastrointestinal tract of Labeo rohita, one of them KADR2 showed higher antagonistic effect against fish pathogens.

\section{References}

Abraham TJ, Babu CHS, Mondal S and Banerjee T. 2007. Effects of dietary supplementation of commercial human probiotic and antibiotic on the growth rate and content of intestinal microflora in ornamental fishes. Bangladesh Journal of Fisheries Research., 11(1):57-63.

Aderolu AZ, Lawal MO, Ali T O and Aarode OO.2011. Utilization of Baker's Yeast (Saccharomyces cerevisiae) in the diet of 
juvenile African Catfish (Clarias gariepinus), Journal of Sci. Res. Dev., 13: $19-27$

Aly SM, AhmedYAG, Ghareeb AAA and Mohamed MF. 2008. Studies on Bacillus subtilis and Lactobacillus acidophilus as potential probiotic on the immune response and resistance of Tilapia nilotica (Oreochromis niloticus) to challenge infections, Fish and Shellfish Immunology, 25:128-136.

AOAC. 1990. Official Methods of Analysis of the Association of Official Analytical Chemists, Vol. 1, 14th edn. 1102 p. Association of Official Analytical Chemists, Arlington, VA, USA.

APHA,American Public Health Association. 1992. Compendium of Methods for the Microbiological Examination of Foods, 2nd ed. APHA, Washington, DC

Ayyappan S, Moza U, Gopalkrishna A, Meenakumari B, Jena JK and Pandey AK. 2011. Handbook of Fisheries and Aquaculture, $2^{\text {nd }}$ edn. Indian, Council of Agriculture Research, New Delhi.

Balcazar JL, DeBlas I, Ruiz-Zarzuela I, Vendrell D and Muzquiz J L. 2004. Probiotics: a tool for the future of fish and shellfish health management, Journal of Aquaculture, 19: 239-242.

Buyuksirit T, Kuleasan H, Antimicrobial agents produced by yeasts. International Journal of Nutrition and Food Engineering, 2011, 8 (10).

Chu WH and Lu CP. 2005. Multiplex PCR assay for the detection of pathogenic Aeromonas hydrophila, Journal of Fish Diseases, 28(7):437-444.

Dhanasekaran, D., S. Saha, N. Thajuddin, M. Rajalakshmi and A. Panneerselvam, (2010). Probiotic effect of Lactobacillus isolates against bacterial pathogens in fresh water fish. Journal of Coastal Development, 13: 103-112.

Ghosh S. 2011. Study of yeast flora from fruit of Syzygium cumini (linn) skeel. Agriculture and Biology Journal of North America ISSN Print: 2151-7517, ISSN Online: 2151-7525

Giri SS, Sen SS, and Sukumaran V. 2012.
Effects of dietary supplementation of potential probiotic Pseudomonas aeruginosa VSG-2 on the innate immunity and disease resistance of tropical freshwater fish, Labeo rohita, Fish \& Shellfish Immunology, 32:1135-114

Gobinath J and Ramanibai R. 2012. Effect of probiotic bacteria culture on pathogenic bacteria from fresh water fish Oreochromis mossambicus. Journal of modern biotechnology, 1(1): 50-54

Gupta A, Dhawan A. 2012. Effect of dietary probobiotic improval (L. sporogenase and $S$. cerevisiae) on growth and feed utilization of $M$ rosenbergai post larvae, Animal Nutr. Feed Tech, 2012-researchgate.net.

Keysami MA, Saad CR, Sijam K, Daud HM, Alimon AR. 2007. Effect of Bacillus subtilis on growth development and survival of postlarvae Macrobrachium rosenbergii (de Man), Aquaculture Nutrition, 13: 131136.

Lara-Flores M, Olvera-Novoa MA, GuzmanMendez BE, Lopez-Madrid W. 2003. Use of the bacteria Streptococcus faecium and Lactobacillus acidophilus, and the yeast Saccharomyces cerevisiae as growth promoters in Nile Tilapia (Oreochromis niloticus), Aquaculture, 216(1-4):193-201

Liu KF, Chiu CH, Shiu YL, Cheng W and Liu CH. 2012. Effects of the probiotic, Bacillus subtilis E20, on the survival, development, stress tolerance, and immune status of white shrimp, Litopenaeus vannamei larvae. Fish and Shellfish Immunology 28:837-844.

Magaldi S, Mata-Essayag S, Hartung de Capriles C, et al., 2004. Well diffusion for antifungal susceptibility testing, Int. $J$. Infect. Dis, 8: 39-45

Mazurkiewicz J, Przybyl A, Sip A and Grajek W. 2008. Effect of Carnobacterium divergens and Enterococcus hirae as probiotic bacteria in feed for common carp, Cyprinus carpio. L, Arch. Polish Fish, 15: 93-102.

Mohapatra S, Chakraborty T, Prusty AK, Kumar K, PaniPrasad K, and Mohanta KN. 2012b. Fenvalerate induced stress mitigation by dietary supplementation of 
multispecies probiotic mixture in a tropical freshwater fish, Labeorohita (Hamilton), Pesticide Biochemistry and Physiology, 104:28-37.

Mohapatra S, Chakraborty T, Prusty AK, Das P, PaniPrasad K, and Mohanta KN. 2012a. Use of different microbial probiotics in the diet of rohu, Labeo rohita fingerlings: effects on growth, nutrient digestibility and retention, digestive enzyme activities and intestinal microflora, Aquaculture Nutrition, 18(1):1-11.

Palod J and Singh V S. 2004. Role of probiotics in broiler feeding. Sadana's All India poultry Business Directory (Year Book 2003-2004) Special Millennium issue, 2nd ed. Sadana publishers and Distributors, Ghaziabad. 147-148.

Roostita LB, Fleet GH, Wendry SP, Apon ZM and Gemilang LU. 2011. Determination of Yeasts Antimicrobial Activity in Milk and Meat Products, Advance Journal of Food Science and Technology, 3(6): 442-445

Rumsey GL, Hughes SG and Kinsella JL. 2007. Use of dietary yeast Saccharomyces cerevisae nitrogen by Lake Trout, Journal of the World Aquaculture Society, 21(3):205-209

Samantaray, K., Mohanty, S.S., 1997. Interactions of dietary levels of protein and energy on fingerling snakehead, Channa striata. Aquaculture, 156: 241- 249.

Schneitz C, Kiickinen T, Toivonen V. 1998. Effect of BROILACT on the physicochemical conditions and nutrient digestibility in the gastrointestinal tract of broilers. Poult. Sci. 77:426-432.

Thankappan B, Ramesh D, Ramkumar S, Natarajaseenivasan $\mathrm{K}$ and Anbarasu, $\mathrm{K}$. 2015. Characterization of Bacillus spp: from the gastrointestinal tract of Labeo rohita - towards to identify novel probiotics against fish pathogens. Appl. Biochem. Biotechnol., 175: 340-353

Vaseeharan B, Lin J,Ramasamy P.2004. Effect of probiotics, antibiotic sensitivity, pathogenicity, and plasmid profiles of Listonella anguillarum-like bacteria isolated from Penaeus monodon culture systems, Aquaculture, 241: 77-91

Venkat HK, Narottam PS and Kamal KJ. 2004. Effect of feeding Lactobacillus-based probiotics on the gut microflora, growth and survival of postlarvae of Macrobrachium rosenbergii (De Man). Aquacul. Res., 35: 501-507.

Venkatalakshmi S and Ebanasar J. 2015. Immunostimulatory effect of Lactobacillus sporogenes on the nonspecific defense mechanisms of Oreochromis mossambicus (Peters), International Journal of Fisheries and Aquatic Studies, 2(4): 362-369

Zhou X., Wang Y, Yao J, and Li W 2010. Inhibition ability of probiotics, Lactococcus lactis against $A$. hydrophila and stud of its immunostimulator effect in tilapia (Oreochromis niloticus), International Journal of Engineering, Science and Technology, 2(7):73-80.

\section{How to cite this article:}

Nityananda Das, Sarita Das, B. K. Khuntia and Brundaban Sahu. 2020. Effect of Feed Probiotic on the Growth and their Colonization Performance on the Intestine of Rohu (Labeo rohita). Int.J.Curr.Microbiol.App.Sci. 9(03): 806-823. doi: https://doi.org/10.20546/ijcmas.2020.903.095 